\title{
IMPLEMENTASI PENDIDIKAN KARAKTER DALAM PEMBINAAN AKHLAK DI SMP UNISMUH MAKASSAR
}

\author{
Nursuci Indriati Sukoco ${ }^{1}$ Nurdin $^{2}$ \\ ${ }^{1}$ Pendidikan Sosiologi, Universitas Muhammadiyah Makassar \\ Email: nursuci@gmail.com \\ 2Pendidikan Sosiologi, Universitas Muhammadiyah Makassar \\ Email: nurdin@unismuh.ac.id \\ ${ }^{3}$ Pendididikan Sosiologi, Universitas Muhammadiyah Makassar \\ Email: kaharuddin@unismuh.ac.id
}

\begin{abstract}
Abstrak. The main problem in this study is Makassar Unismuh Middle School is a religion-based school but there are still students who often make deviations that do not reflect the character of religious, honest, and disciplined. This study aims to find out how the implementation and concept of character education in character building in Makassar Unismuh Middle School. The purpose of this study is (i) to find out the implementation of character education in moral development in Unismuh Makassar Middle School, (ii) to find out the concept of moral development so that it becomes a character in Makassar Unismuh Middle School. This type of research is a descriptive qualitative research method. The location of this research was conducted at Unismuh Makassar Middle School. With the number of informants as many as 10 technical people in determining this informant is done in 3 ways namely key informants, key informants and additional informants. Data collection techniques used are observation, interviews and documentation. The data obtained were analyzed using qualitative descriptive with stages of reducing data, displaying data and drawing conclusions. The validity of the data used is source triangulation, time triangulation and technique triangulation. The results of the research in the field that, (i) show that the role of the teacher in implementing character education is very important. Character building at school starts early in the morning to create conditions conducive to the development of learners' character and all learning activities must be touched by character education. (ii) Development of students' morals from personal personal lack of attention of parents towards their children, so students still do deviant behavior because of the lack of self-defense of students in following the times so that they are easily influenced by friends, and the surrounding environment.
\end{abstract}

Keywords: Character Education, Morals

\begin{abstract}
Abstrak. Masalah utama dalam penelitian ini adalah SMP Unismuh Makassar merupakan sekolah yang berbasis agama namun siswa-siswanya masih ada yang sering melakukan penyimpangan yang tidak mencerminkan karakter religious,jujur, dan disiplin. Penelitian ini bertujuan untuk mengetahui bagaimana implementasi dan konsep pendidikan karakter dalam pembinaan akhlak di SMP Unismuh Makassar. Tujuan dari penelitian ini adalah (i) untuk mengetahui implementasi pendidikan karakter dalam pembinaan akhlak di SMP Unismuh Makasar, (ii) untuk mengetahui konsep pembinaan akhlak sehingga menjadi karakter di SMP Unismuh Makassar. Jenis penelitian yang digunakan adalah metode penelitian kualitatif deskriptif. Lokasi penelitian ini dilakukan di SMP Unismuh Makassar. Dengan jumlah informan sebanyak 10 orang teknik dalam menentukan informan ini dilakukan dengan 3 cara yaitu infoman kunci, informan utama dan informan tambahan. Teknik pengumpulan data yang digunakan yaitu observasi, wawancara dan dokumentasi. Data yang diperoleh dianalisis dengan menggunakan deskriptif kualitatif dengan tahapan mereduksi data, mendisplaykan data dan penarikan kesimpulan. Teknik keabsahan data yang digunakan yaitu triangulasi sumber, triangulasi
\end{abstract}


waktu dan tringulasi teknik. Hasil penelitian dilapangan bahwa, (i) menunjukan bahwa peran guru dalam mengimplementasikan pendidikan karakter itu sangat penting. Pembinaan karakter disekolah dimulai dari awal pagi untuk menciptakan kondisi kondusif bagi perkembangan karakter peserta didik dan semua kegiatan pembelajaran harus tersentuh dengan pendidikan karakter. (ii) Pembinaan akhlak peserta didik dari personal diri pribadi kurangnya perhatian orang tua terhadap anaknya, jadi peserta didik masih melakukan penyimpangan perilaku karena kurangnya pertahan diri peserta didik dalam mengikuti perkembangan zaman sehingga mudah terpengaruh oleh teman, dan lingkungan di sekitarnya.

Kata kunci : Pendidikan Karakter, Akhlak

\section{PENDAHULUAN}

Pendidikan merupakan upaya sadar dan terencana untuk mewujudkan suasana belajar dan proses pembelajaran agar peserta didik secara aktif mengembangkan potensi dirinya untuk memiliki kekuatan spritual keagamaan, pengendalian diri, kepribadian, kecerdasan, ahlak mulia serta keterampilan yang diperlukan dirinya, masyarakat, bangsa dan Negara, itulah pengertian pendidikan menurut undang-undang sisdiknas No 20 tahun 2003.

Menurut Lagevelend sebagaimana dikutip oleh Hasbullah (2015) pendidikan adalah setiap usaha, pengaruh, perlindungan, dan bantuan yang diberikan kepada anak tertuju kepada kedewasaan anak itu, atau lebih tepat membantu anak supaya terampil melaksanakan tugas hidupnya sendiri. Penerapan pendidikan karakter dapat dilaksanakan pada nilai-nilai pendidikan karakter dan objek kajian adalah masyarakat, sehingga di harapkan peserta didik dapat berbaur dan dapat memiliki kepribadian yang harus benar-benar diterapkan agar mendapat karakter yang baik yang semestinya .

Diantara isu penting yang sedang mencuat permukaan dalam dunia pendidikan saat ini, khususnya di Indonesia adalah pendidikan karakter. Hal ini tersebut merupakan peraturan dari presiden Joko Widodo tentang PPK (penguatan pendidikan karakter). Hal ini perlu digalakan dengan tujuan menyelesaikan problem kemunduran pendidikan bangsa dan fenomena tingginya kasus asusila di Indonesia seperti pergaulan bebas, hamil diluar nikah, aborsi, narkoba, tawuran, aids, putus asa dan lainya.

Pendidikan karakter bertujuan agar generasi bangsa memiliki kepribadian yang mulia serta memiliki bekal yang cukup untuk menjalani kehidupan dengan keadaan zaman yang semakin terbuka dan dinamis ini. Pembinaan Akhlak yang baik bagi anak semakin terasa diperlukan terutama pada saat manusia di zaman modern ini dihadapkan pada masalah moral dan akhlak yang cukup serius, yang kalau dibiarkan akan menghancurkan masa depan bangsa. Setiap orang tua hendaknya waspada terhadap ancaman arus globalisasi yang akan menggerus kepribadian anak.

Dengan pendidikan yang baik, tentu akhlak manusia pun juga akan lebih baik Tapi kenyataanya dalam hidup ini, banyak orang yang menggunakan akal dan kepintaranya untuk maksiat, Banyak orang yang pintar dan berpendidikan justru ahlaknya lebih buruk dibanding dengan orang yang tak pernah sekolah. Hal ini terjadi karena ketidak seimbangnya ilmu dunia dan akhirat. Ilmu pengetahuan dunia rasanya kurang kalau belum dilengkapi dengan ilmu agama atau akhirat. Dalam pembinaan akhlak diperlukan adanya strategi khusus agar Pembinaan Akhlak peserta didik dapat berhasil. Keteladanan dan pembiasaan dalam pendidikan amat dibutuhkan karena secara psikologis, anak didik lebih banyak mencontoh prilaku atau sosok figur yang diidolakannya termasuk gurunya. Pembiasaan juga tak kalah pentingnya dalam kegiatan pembelajaran. Hal ini disebabkan karena setiap pengetahuan atau tingkah laku yang diperoleh dengan pembiasaan akan sangat sulit mengubah atau menghilangkannya sehingga cara ini amat berguna dalam mendidik anak. 


\section{KAJIAN PUSTAKA}

Tindakan sosial menurut max weber adalah suatu tindakan individu sepanjang tindakan itu mempunyai makna atau arti subjektif bagi dirinya dan diarahkan kepada tindakan orang lain. Suatu tindakan individu yang diarahkan kepada benda mati masuk dalam kategori social. Suatu tindakan dikatakan sebagai tindakan social ketika tindakan tersebut benar-benar diarahkan kepada orang lain. Weber membedakan tindakan social manusia kedalam empat tipe yaitu :

a) Tindakan rasional instrumental (zwerk rational) Tindakan ini memperoleh suatu tindakan social yang dilakukan seseorang didasarkan atas pertimbangan dan pilihan sadar yang berhubungan dengan tujuan tindakan itu dan ketersediaan alat yang dipergunakan untuk mencapainya,tindakan ini dilakukan untuk mencapai tujuan dengan pertimbangan rasional.

b) Tindakan rasional nilai (Werk rational) Tindakan rasional nilai memiliki sifat bahwa alat-alat yang ada hanya merupakan pertimbangan dan perhitungan yang sadar, sementara tujuantujuanya sudah ada didalam hubunganya dengan nilai-nilai individu yang bersifat absolut,tindakan yang dilakukan berdasarkan pertimbangan nilai etika, adat maupun nilai lainya.

c) Tindakan afektif/tindakan yang dipengaruhi emosi/affectual action. Tindakan social ini lebih didominasi perasaan atau emosi tanpa reflex intelektual atau perancanaan sadar. Tindakan afektif sifatnya spontan, tidak rasional, dan merupakan ekspresi emosional dari individu.

d) Tindakan tradisional/tindakan karena kebiasaan/traditional action. Tindakan ini, seseorang memperlihatkan perilaku tertentu karena kebiasaan yang diperoleh dari nenek moyang, tanpa refleksi yang sadar atau perencanaan.

\section{METODE PENELITIAN}

Jenis penelitian yang digunakan dalam penelitian ini berupa penelitian kualitatif deskriftif, yang sesuai dengan masalah yang dihadapi, dalam Penelitian ini merupakan penelitian kualitatif yaitu penyelidikan mendalam dengan melakukan suatu prosedur penelitian lapangan yang menggunakan data deskriptif berupa kata-kata tertulis atau lisan dari orang-orang, perilaku yang dapat diamati dan fenomena-fenomena yang muncul, sehingga penelitian ini menggunakan pendekatan kualitatif. Pendekatan kualitatif menekankan pada makna, penalaran, definisi suatu situasi tertentu dan dalam konteks tertentu, lebih banyak meneliti dalam kehidupan sehari-hari.

Pendekatan penelitian yang digunakan penelitian kualitatif deskriftif yaitu pendekatan studi kasus "case study" adalah bagian dari metode kualitatif yang hendak mendalami suatu kasus tertentu secara lebih mendalami dengan melibatkan pengumpulan beraneka sumber informasi dimana peneliti hendak mendalami permasalahan yang akan dijadikan sebagai bahan peneliti dengan tujuan yang ingin di capai. Pada jenis penelitian ini peneliti benar-benar mampu menemukan suatu cara yang tepat yang dapat memecahkan masalah yang akan diteliti karena pada penelitian ini peneliti yang berperan aktif.

Hal-hal yang menjadi sasaran penelitian dalam peneliatn ini adakah implementasi pendidikan karakter dalam pembinaan akhlak. Dalam penelitian Teknik pengambilan informan yang di gunakan penelitian adalah snowball sampling yaitu dengan memilih secara langsung informan berdasarkan kriteria yang telah ditentukan peneliti. Jumlah informan dalam penelitian 10 orang. ada pun yang menjadi informan kunci adalah peserta didik, informan utama yaitu peserta didik dan informan tambahan yaitu guru. Jenis data dalam penelitian ini yakni Data primer (data yang diperoleh secara langsung dari sumber) dan data Sekunder (data yang diperoleh melalui media). Ada pun tekhik pengumpulan data yang dilakukan dalam peneliti ini adalah: observasi, wawancara, dan dokumentasi. Untuk memperoleh hasil penelitian yang lengkap, tepat dan benar, maka diperlukan metode yang valid dalam menganalisis data. 


\section{HASIL DAN PEMBAHASAN}

\section{Hasil Penelitian}

\section{Implementasi Pendidikan Karakter Dalam Pembinaan Akhlak di SMP Unismuh Makassar}

Implementasi merupakan suatu tindakan untuk menerapkan suatu kaidah, nilai atau norma tertentu yang telah dipahami dan menjadi standar dalam bertindak atau bersikap. Pendidikan karakter harus diupayakan dengan terencana dan terperinci guna dilaksanakan secara sistimatis dan berkeseimbangan untuk membantu peserta didik dalam mengimplementasikan nilai-nilai kebaikan yang berhubungan dengan Tuhan Yang Maha Esa, diri sendiri, sesama manusia lainya, lingkungan, bangsa dan Negara yang diwujudkan dalam pikiran, perasaan, sikap, perkataan dan perbuatan. Sebagaimana data yang ada sudah cukup baik dalam menerima pendidikan karakter terutama nilai karakter religious dimana sikap dan perilaku yang dilakukan oleh siswa yang melaksanakan ajaran agama yang dianutnya, Dapat disimpulkan bahwa penilaian pendidikan karakter harus dilakukan terus-menerus untuk mengetahui perkembangan karakter peserta didik yang disesuiakan dengan nilai-nilai agama, budaya, bangsa dan negara.

Berdasarkan hasil tentang implementasi pendidikan karakter yang diterapkan disekolah, yaitu dengan melibatkan semua komponen baik dari pendidik. Untuk melaksanakan proses belajar mengajar antara guru dengan peserta didik, dalam interaksi antara guru dan peserta didik berlangsung dilingkungan sekolah. Karena pendidikan karakter merupakan suatu system penenaman nilai-nilai karakter yang juga harus didukung semua pihak yang disertai dengan kesadaran, kepedulian, pemahaman, dan komitmen yang tinggi untuk melaksanakan nilai-nilai tersebut. Adapun tujuannya adalah memicu kesadaran peserta didik untuk mendisiplinkan diri dan menanamkan karakter dan akhlak yang baik. Dengan demikian pengaruh yang didapatkan dari nilai-nilai karakter yang diintegrasikan ke dalam semua mata pelajaran pada proses belajar mengajar di SMP Unismuh Makassar, sehingga peserta didik memahami pentingnya nilai-nilai karakter dan membuat peserta didik lebih disiplin, patuh dan taat pada aturan yang berlaku. Pelaksanaan pendidikan karakter melibatkan berbagai pihak tidak hanya di sekolah, tetapi juga melibatkan keluarga dan masyarakat dalam keberhasilannya. Begitu pula dengan pelaksanaan pendidikan karakter dalam akhlak di SMP Unismuh Makassar.

\section{Konsep Pembinaan Akhlak Sehingga Menjadi Karakter di SMP Unismuh Makassar}

Pembinaan yang dimaksud disini adalah merupakan usaha kegiatan yang mengarahkan peserta didik dalam melaksankan suatu kegiatan pendidikan yang baik secara teori maupun praktek agar kegiatan berjalan sesuai dengan tujuan yang diinginkan.

Pelaksanaan pembinaan akhlak di SMP Unismuh Makassar harus melaksanakan tugas dan tangung jawabnya dengan baik yang salah satunya adalah melakukan pembinaan akhlak peserta didik. Dalam pembinaan akhlak, pelaksanan pembinaan akhlak siswa yang diharapkan adalah :

a. Menanamkan nilai-nilai agama Yaitu memberikan dalil-dalil atau dasar-dasar pada akhlak itu sendiri melalui al-quran dan hadist.

b. Memberi contoh perbuatan yang baik yang terpenting adalah dewan guru dapat memotivasi atau menasehati peserta didik dan memberi contoh secara langsung dan memberi akhlak dan perbuatan yang baik.

c. Menegur yang berakhlak buruk. Strategi khusus yang dilakukan dengan metode pembiasaan, paksaan, dan teguran.

d. Memotivasi beribadah kepada Allah

Berdasarkan hasil interview membina peserta didik yang dilakukan di sekolah dengan memotivasi untuk selalu beribadah kepada Allah. Akhlak disekolah ini sangat penting dilakukan agar peserta didik terbagun suatu kebiasaan positif dalam hidupnya untuk senantiasa beribadah kepada 
Allah dan tidak mudah meninggalkan ibadah kecuali diperbolehkan menurut ajaran agama islam dan nantinya pada saat mereka menempuh kehidupan setelah sekolah atau alumni dari sekolah.

Di SMP Unismuh Makassar dalam pemberian hukuman kepada peserta didik cukup membangun akhlak dan karakter yang akan menjadikan peserta didik lebih baik, sehingga proses pembinaan akhlak dapat berjalan dengan baik bukan hanya dalam proses belajar mengajar tetapi bisa dengan pemberian hukuman kepada siswa, Sehingga pembinaan akhlak bisa juga dilakukan dengan hukuman dari kesalahan siswa untuk membangun akhlak siswa agar lebih baik.

\section{PEMBAHASAN}

\section{Implementasi Pendidikan Karakter Dalam Pembinaan Akhlak di SMP Unismuh Makassar}

Gambaran hasil penelitian dengan teori yang digunakan, teori yang digunakan ini adalah teori tindakan social max weber dimana suatu tindakan social ketika rindakan tersebut benar-benar diarahkan kepada orang lain, max weber membedakan tindakan social manusia kedalam empat tipe yakni tindakan rasional instrumental, tindakan rasional nilai, tindakan efektif, dan tindakan tradisional. Disekolah teori tindakan rasional nilai yang selalu dibutuhkan oleh setiap guru untuk menilai peserta didik baik dikelas maupun diluar kelas dimana tindakan rasional nilai menurut max weber menyatakan bahwa tindakan yang dilakukan berdasarkan pertimbangan nilai etika, adat maupun nilai lainya, dan termaksud nilai-nilai karakter pada peserta didik. Mengenai pendidikan karakter dalam pembinan akhlak disekolah tentunya, pelaksanaanya semua kegiatan pembelajaran harus tersentuh dengan pendidikan karakter, jadi siapa pun gurunya tentu harus menanamkan sebuah pendidikan karakter yang baik dalam pembelajaran apa pun itu bukan hanya sekedar pembelajaran agama. Pelaksanaan pendidikan karakter bukan hanya pada saat pembelajaran berlangsung, tetapi di mulai sebelum pembelajaran dilaksanakan, yaitu dengan membuat rencana pembelajaran yang berbasis karakter. Selain itu, pendidikan karakter juga membutuhkan keteladanan dari guru untuk menunjang keberhasilannya sehingga dalam hal ini guru harus menjadi contoh bagi peserta didik dalam bersikap, berbicara dan berpenampilan.

\section{Konsep Pembinaan Akhlak Sehingga Menjadi Karakter di SMP Unismuh Makassar}

Gambaran hasil penelitian dengan teori yang digunakan yakni teori tindakan rasional nilai oleh max weber, dengan tujuan untuk mencapai nilai-nilai karakter yang muncul pada peserta didik dalam hal konsep pembinaan akhlak oleh guru, untuk mempermudah guru mengetahui nila karakter yang tertanam pada diri peserta didik baik di kelas maupun di luar kelas. Pembinaan yang dimaksud disini adalah merupakan usaha kegiatan yang mengarahkan peserta didik dalam melaksankan suatu kegiatan pendidikan yang baik secara teori maupun praktek agar kegiatan berjalan sesuai dengan tujuan yang diinginkan. Sedangkan akhlak menunjukan bahwa kebiasaan atau sikap yang mendalam dalam jiwa manusia dimana timbul perbuatan dengan mudah tanpa mempertimbangkan terlebih dahulu yang dilakukan berulang-ulang hingga menjadi kebiassan dan perbuatan itu mengarah kepada perbuatan yang baik atau buruk.

Menanamkan nilai-nilai agama yaitu memberikan dalil-dalil atau dasar-dasar pada akhlak itu sendiri melalui al-quran dan hadist. Menegur yang berakhlak buruk strategi khusus yang dilakukan dengan metode pembiasaan, paksaan,dan teguran. Memotivasi beribadah kepada Allah membina peserta didik yang dilakukan disekolah dengan memotivasi untuk selalu beribadah kepada Allah Berdasarkan hasil, akhlak disekolah ini sangat penting dilakukan agar peserta didik terbagun suatu kebiasaan positif dalam hidupnya untuk senantiasa beribadah kepada Allah dan tidak mudah meninggalkan ibadah kecuali diperbolehkan menurut ajaran agama islam dan nantinya pada saat mereka menempuh kehidupan setelah sekolah. 


\section{KESIMPULAN}

Berdasarkan hasil penelitian tentang Implementasi Pendidikan Karakter Dalam Pembinaan Akhlak Di SMP Unismuh Makassar maka dapat disimpulkan:

Implementasi pendidikan karakter dalam pembinaan akhlak, Mengenai pendidikan karakter dalam pembinan akhlak disekolah tentunya, pelaksanaanya semua kegiatan pembelajaran harus tersentuh dengan pendidikan karakter, Pembinaan karakter kita disekolah ini dimulai dari awal pagi, ada apel setiap hari, apel untuk menanamkan karakter disiplin, setelah itu shalat itu karakternya religious, kemudian pelaksanan lain itu dalam hal kultum itu karakter percaya diri kemudian budayabudaya lainya. Pendidikan karakter yang dimaksud disini adalah bahwa peran guru sangat penting dalam rangka pembentukan atau pembangan karakter. Pelaksanaan pembinaan akhlak di SMP Unismuh Makassar harus melaksanakan tugas dan tangung jawabnya dengan baik yang salah satunya adalah melakukan pembinaan akhlak peserta didik. Menanamkan nilai-nilai agama Yaitu memberikan dalil-dalil atau dasar-dasar pada akhlak itu sendiri melalui al-quran dan hadist. Memberi contoh perbuatan yang baik yang terpenting adalah dewan guru dapat memotivasi atau menasehati peserta didik dan memberi contoh secara langsung dan memberi akhlak dan perbuatan yang baik, menasehati dan memotivasi, Menegur yang berakhlak buruk Strategi khusus yang dilakukan dengan metode pembiasaan, paksaan,dan teguran. Memotivasi beribadah kepada Allah membina peserta didik yang dilakukan di sekolah dengan memotivasi untuk selalu beribadah kepada Allah, akhlak disekolah ini sangat penting dilakukan agar peserta didik terbagun suatu kebiasaan positif dalam hidupnya untuk senantiasa beribadah kepada Allah dan tidak mudah meninggalkan ibadah. Kemudian, untuk masalah karakter dan pembinaan akhlak peserta didik di SMP Unismuh Makassar pada dasarnya sudah berjalan dengan baik. Hanya saja peserta didik masih melakukan perilaku meyimpang karena kurangnya pertahanan diri peserta didik dalam mengikuti perkembangan zaman sehingga mudah terpengaruh oleh teman dan lingkungan, serta kurangnya pengawasan dan perhatian orang tua yang mengakibatkan peserta didik mencari perhatian di sekolah.

\section{DAFTAR PUSTAKA}

Abubakar Barja, Psikoogi Konseling dan Tehnik Konseling, Jakarta: Studia Press,2004 ).Cet.Ke -1 h,12 Alwi, Hasan. 2007. Kamus Besar Bahasa Indonesia. Jakarta: Balai Pustaka.

Arikunto,Suharsimi.2010. Prosedur Penelitian Suatu Pendekatan Praktek. Jakarta: Rineka Cipta.

Asmani Ma'mur, Jamal,2016.Buku Panduan Internalisasi Pendidikan Karakter di Sekolah. PT Diva Press.

Azmi, Muhammad,2016. Pembinaan Ahlakanak Usia Pra Sekoah Yogyakarta: Belukar.

Berkowitz, M.W. \& Bier,M.C.2016. What Works In CharacterEducation: A Research-Driven Guide for Educators, Washington DC: Univesity of Missouri- St Louis.

Creswell.2012. Pendekatan Kualitatif, Kuantitatif, Yogyakarta : Pustaka Pelajar.

Depertemen Pendidikan Nasional, 2016. Kamus Besar Bahasa Indonesia, Edisi tiga, Jakarta: Balai Pustaka. Edisi ke.1V, h.623. 2017 Edisi ke IV.

Fritjof Capra,Titik Balik Peradaban; Sains, Masyarakat dan Kebangkitan Kebudayaan,(Jakarta:Banteng Pustaka,2015) cetakan ke-VI,hlm.8-43.

Guntur Setiawan, Implementasi dalam Birokrasi Pembangunan,(Bandung, Remaja Rosda Karya, 2016), hal.39

Hanifa Harsono, Implementasi Kebijakan dan Politik,(Bandung Mutiara Sumber Widya,20017),hal.67. Hasbullah.2015, Dasar-dasar Ilmu pendidikan. Jakarta : Raja Gravindo Perseda.

Haedar nashir, Pendidikan Karakter Berbasis Agama \& Budaya,(Yogyakarta, Multi Presindo,2016),h 93-94

Hasan, M. (2006). Membentuk Pribadi Muslim. Yogyakarta: Pustaka Nabawi.

H.E. Mulyasa, Manajemen pendidikan karakter,(Jakarta,bumi Aksara,2017),h.9.

Kementrian Pendidikan Nasional.Direktorat Jendral Manajemen Pendidikan Dasar dan Menegah. 2015. Pembinaan pendidikan karakter disekolah menegah pertama. Jakarta 
Kementerian Pendidikan Nasional. 2016. Pengembangan Pendidikan Budaya danKarakter Bangsa: Pedoman Sekolah. Jakarta:Badan Penelitian dan Pengembangan Pusat Kurikulum.

Mardalis, Metode Penelitian Suatu Pendekatan Proposal, (Jakarta: Bumi Aksara, 2015)

Merriam webster's, Merriam-webster's Collegiate Dictionary,(U.S.A: Merriam Webster's Incorporated,2016,ce. 7,h.624

Mohammad Atiyah Al-abrsy, Dasar-Dasar Pokok Pendidikan Islam, Terjemah H.Bustami Dan a. Ghani, (Jakarta: Bulan Bintang,2016), cet.ke -4,h.104

Muchlas Samani dan Hariyanto, Konsep dan Model Pendidikan Karakter, (Jakarta: Remaja Rosda Karya, 2015),hlm,44-45. 2017, Cet.1,h.43.

Nurla Isna Aunillah, Panduan Menerapkan Pendidikan Karakter di Sekolah, ( Jogjakarta: Laksana, 2017), h.19.

Nurdi Usman, (2016) Konteks Implementasi Berbasis Kurikulum,(Jakarta: raja grafindo persada,), hal.70

Proyek Penerapan Bimbingan Dakwah Agama,Bimbingan Rohani Islam Pada Darmawanita,( Jakarta: departemen agama,2016),h,8.

Pusat kurikulum Kementrian Pendidikan Nasional, Pedoman Pelaksanaan Pendidikan Karakter, (Jakarta : puskurbuk,2015) hlm.3-42

Raharjo,Susilo \& Gudnanto. (2011).Pemahaman Individu Tehknik Non Tes, Kudus, Nora Media Enterprise.

Samani, Muclas dan Hariyanto. 2011. Konsep dan Model Pendidikan Karakter. Bandung: Remaja Rosdakarya.

Siddiqoh,D. 2014. Skripsi. Implementasi Pendidikan Karakter Dalam Mengajar Kepemimpinan Kepada Madrasah dan Mengajar Pembelajaran Guru MI Se-Kecamatan Pabelan Kabupaten Semarang. UIN Salatiga Press.

Sugiyono.2016. Metode Penelitian Pendidikan. Bandung : Alfabeta._2016. Metode Penelitian Kuantitatif, Kualitatif dan R\&D. Bandung: Alfabeta.

Walgito,Bimo. (2010). Bimbingan dan Konseling Studi\& Karir. Yogyakarta : Andi.

Winkel,WS \& Hastuti,Sri.(2004). Bimbingan dan Konseling Di Institusi Pendidikan, Yokyakarta : Media Abadi.

Ys. Majo, Kamus Populer, ( Surabaya:Beringin Jaya, 2016,)Cet. Ke-,h.24

Zubaedi, Desain Pendidikan Karakter Konsepsi dan Aplikasinya Dalam Lembaga Pendidikan, (Jakarta: Kencana Prenada Media Type equation here.a Group ,2017),h.9

Zubaedi. 2016. Desain Pendidikan Karakter Konsepsi dan Aplikasinya dalam Lembaga Pendidikan. Jakarta: Prenada Media Group.(Jakarta : Kencana,2017),h. 74

Zuriah, Nurul. 2009. Metodologi Pendidikan Sosial dan Pendidikan. Jakarta:Sinar Grafika. 